\begin{tabular}{|c|c|}
\hline $\begin{array}{l}\text { Chemistry of } \\
\text { Metals and Alloys }\end{array}$ & $\begin{array}{l}\text { Chem. Met. Alloys } 2 \text { (2009) 89-93 } \\
\text { Ivan Franko National University of Liv } \\
\text { www.chemetalatjournal.org }\end{array}$ \\
\hline
\end{tabular}

\title{
Spectrophotometric methods for osmium determination using organic reagents: application to intermetallides
}

\author{
Mariana V. RYDCHUK ${ }^{1}$, Galyna M. MYKHALYNA ${ }^{1}$, Oksana S. BONISHKO ${ }^{1}$, Olga P. DOBRYANSKA ${ }^{1}$, \\ Teodoziya Ya. VRUBLEVSKA ${ }^{1}$ \\ ${ }^{1}$ Ivan Franko National University of Lviv, Faculty of Chemistry, Department of Analytical Chemistry, \\ Kyryla i Mefodiya St., 6, 79005, Lviv, Ukraine \\ *Corresponding author.Tel.: +380-32-2394048; e-mail: galyna_myhalyna@yahoo.com
}

Received June 18, 2009; accepted June 30, 2009; available on-line November 16, 2009

\begin{abstract}
The present work describes the application of new spectrophotometric methods to the determination of osmium in the intermetallides $\mathrm{Nd}_{20} \mathrm{Os}_{15} \mathrm{Si}_{65}$ and $\mathrm{Nd}_{10} \mathrm{Os}_{30} \mathrm{Si}_{60}$. The methods are based on the interaction of osmium with azo dyes (Tropaeolin O, Tropaeolin OOO-I, Eriochrome Black T), flavonoids (morin and quercetin) or Tiron. They are simple and rapid. The sensitivity varies from 0.005 to $0.8 \mu \mathrm{g} \mathrm{ml}^{-1}$; the effective molar absorptivity is $\sim 10^{3}-10^{5} \mathrm{M}^{-1} \cdot \mathrm{cm}^{-1}$, depending on the reagent.
\end{abstract}

Intermetallides / Osmium(IV) / Spectrophotometric determination / Organic reagents

\section{Introduction}

Alloys containing osmium possess unique physical and chemical properties, especially refractoriness in combination with high corrosion-resistance and high conductivity. For these reasons these alloys have wide practical application in modern technology. Osmium alloys are also perspective materials in context with the development of histological research, organic synthesis and the necessity of new equipment with long-life working cathodes [1].

The evaluation of the osmium content in intermetallides obtained after fusion is an important task. The quantitative determination of osmium in complex samples usually demands considerable efforts at all stages of the analysis, because Os is disposed to participate in redox processes and dissolution of the samples can be accompanied by osmium losses as a result of incomplete dissolving and the formation of volatile $\mathrm{OsO}_{4}$. Unfortunately, the number of spectrophotometric methods providing rapid quantitative determination of osmium in real samples is rather small [2]. Spectrophotometric methods involving organic reagents are often used in the analytical practice, though most of these methods demand complicated sample preparation, e.g. preliminary separation of osmium in the form of tetraoxide, or the extraction of coloured osmium compounds by means of organic solvents. New fields of use of spectrophotometry have recently appeared in analyses of PGE (platinum group elements), e.g. numerous new materials based on PGE, which are usually systems of few components, but with a variable range of PGE content [2]. Therefore the search for new accessible, selective and sensitive reagents, which would make it possible to determine the total osmium content, independently of the form of osmium in the analyte, is the actual task.

There exist literature data concerning the application of acidic monoazo dyes, $o, o^{\prime}$-dyhydroxo substituted azo dyes, flavonoids and Tiron as perspective and accessible spectrophotometric reagents. The structural formulas of these organic reagents and their application in spectrophotometric analyses are presented in Table 1.

According to the tabulated data, the abovementioned organic reagents have previously not been used for the spectrophotometric determination of osmium. We have, for the first time, investigated the interaction of osmium(IV) with these reagents, established the optimal conditions for the reactions and elaborated new methods of spectrophotometric determination of osmium on this basis [15-20]. The metrological characteristics of these methods are presented in Table 2.

The selectivity of Os(IV) determination with the examined organic reagents has also been investigated, as well as the masking of interferents. The accuracy of the methods has been verified by analyses of model solutions in the presence of PGE and other metal ions and masking agents using the method "added-found" (relative standard deviations $S_{\mathrm{r}}<0.05$ ). According to the experimental results the elaborated spectrophotometric methods can be used for the 
M.V. Rydchuk et al., Spectrophotometric methods for osmium determination ...

Table 1 The organic reagents used in this work, and their previous spectrophotometric applications.

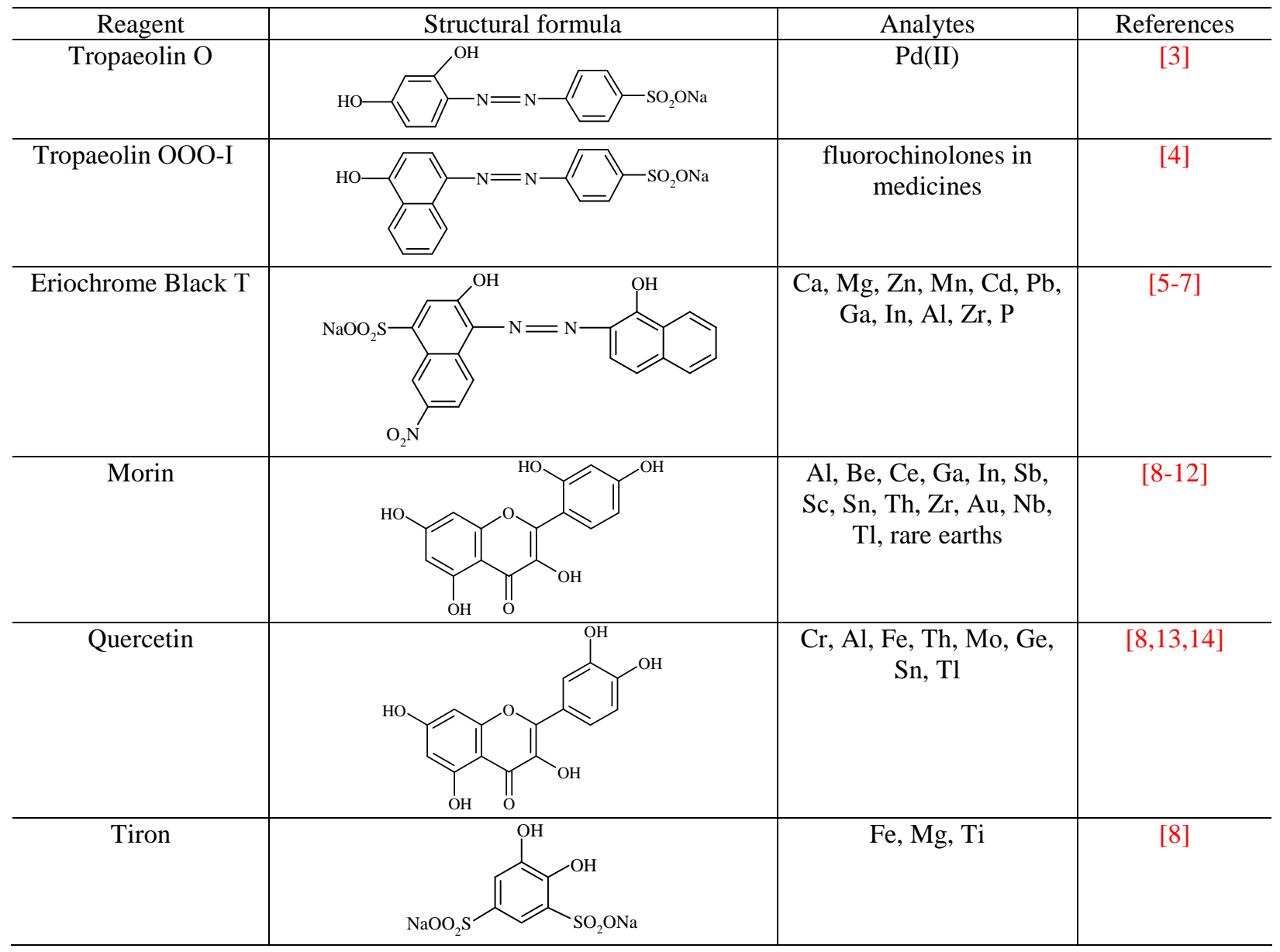

Table 2 Metrological characteristics of the spectrophotometric determination of osmium(IV) with organic reagents.

\begin{tabular}{c|c|c|c}
\hline Reagent & $\begin{array}{c}\text { Linearity range } \\
C_{\text {Os }}, \mu \mathrm{g} \mathrm{ml}^{-1}\end{array}$ & $\begin{array}{c}\text { Limit of quantification, } \\
\mu \mathrm{g} \mathrm{ml}\end{array}$ & $\begin{array}{c}\text { Correlation } \\
\text { coefficient R }\end{array}$ \\
\hline Tropaeolin O & $0.57-28.67$ & 0.29 & 0.9994 \\
Tropaeolin OOO-I & $0.01-1.15$ & 0.005 & 0.9981 \\
Morin & $0.07-0.72$ & 0.07 & 0.9991 \\
Quercetin & $0.18-1.45$ & 0.15 & 0.9992 \\
Eriochrome Black T & $2.8-142.7$ & 0.8 & 0.9999 \\
Tiron & $0.19-17.88$ & 0.05 & 0.9995 \\
\hline
\end{tabular}

determination of osmium in various complex samples, e.g. in different alloys, which contain osmium and other PGE.

In the present work we have tried to generalize and compare the results of the spectrophotometric methods elaborated for osmium determination in our previous works [15-20], and applied these methods to the determination of osmium in alloys.

\section{Experimental}

All aqueous solutions used in the research were prepared using distilled water. All chemicals were of analytical grade.

A stock solution of $\mathrm{Os}(\mathrm{IV}) \quad\left(\mathrm{H}_{2} \mathrm{OsCl}_{6}\right)$ was prepared by dissolving a well defined mass of $\mathrm{OsO}_{4}$, stored in a hermetically sealed glass ampoule, in 
Table 3 Conditions for the spectrophotometric determination of osmium(IV) in $\mathrm{Nd}_{20} \mathrm{Os}_{15} \mathrm{Si}_{65}$ and $\mathrm{Nd}_{10} \mathrm{Os}_{30} \mathrm{Si}_{60}$.

\begin{tabular}{|c|c|c|c|c|c|}
\hline Reagent & Medium & $\mathrm{pH}$ & $\begin{array}{l}\text { Time of reaction, } \min \\
\left(\sim 95^{\circ} \mathrm{C}\right)\end{array}$ & $\lambda, \mathrm{nm}$ & $l, \mathrm{~cm}$ \\
\hline Tropaeolin $\mathrm{O}$ & $0.25 \mathrm{M}$ acetate buffer & 5.2 & 10 & 540 & 5 \\
\hline Tropaeolin OOO-I & $0.01 \mathrm{M}$ sodium tetraborate & 8.0 & 30 & 364 & 3 \\
\hline Morin & $1.2 \times 10^{-4} \mathrm{M}$ sodium tetraborate & 9.5 & 30 & 485 & 1 \\
\hline Quercetin & $0.1 \mathrm{M}$ sodium chloride & 10.0 & 5 & 440 & 1 \\
\hline Eriochrome Black T & $0.01 \mathrm{M}$ sodium tetraborate* & 10.0 & $10 * *$ & 400 & 5 \\
\hline Tiron & $5.0 \times 10^{-4} \mathrm{M}$ sodium tetraborate* & 9.5 & 5 & 440 & 3 \\
\hline
\end{tabular}

concentrated hydrochloric acid, following the modified method described in [21]. The resulting osmium solution was kept for one month to complete the reduction of $\mathrm{OsO}_{4}$ to $\left[\mathrm{OsCl}_{6}\right]^{2-}$. The identification of the Os(IV) solutions was carried out spectrophotometrically, comparing the electronic absorption spectra of the obtained solutions with literature data [22,23]. Standardization of the stock osmium solutions was carried out titrimetrically using potassium iodide. The standard working Os(IV) solutions were prepared by dissolving an aliquot of the osmium(IV) stock solution in $\sim 0.5-1 \mathrm{M} \mathrm{HCl}$.

Organic reagent solutions were prepared from commercially available chemicals. Solutions of Tropaeolin O ("Synbias", Ukraine), Tropaeolin OOOI (Shostkinsky Chemical Plant, Ukraine), Eriochrome Black Т (“ВТЦ МЦ УХII 97-58”, Mosgor, Russia), and Tiron (“ВТЦ МЦ УХII 97-58”, Mosgor, Russia) were prepared by dissolving appropriate amounts of the reagents in distilled water. Solutions of morin ("LOBA CHEMIE" Austranal Präparate, Czech Republic) and quercetin ("CHEMAPOL" Praha, Czech Republic) were prepared by dissolving the reagent in ethanol.

UV-VIS measurements were performed using the following devices: UV-VIS scanning spectrophotometer CARY.WIN - UV-VIS-50, Varian (USA), spectrophotometer HACH DR/4000V (USA), spectrophotometer UV-VIS SPECORD M 40 (CARL ZEISS, JENA, Germany), and photometers KFK-2 UHL 4.2 and KFK-3 - UHL 4.2 (Zagorsky Mechanooptical Plant, Russia). The pass length of the cuvettes was in the range $1-5 \mathrm{~cm}$ for optimal measurements. All absorbance measurements were performed at $\sim 20^{\circ} \mathrm{C}$. The $\mathrm{pH}$ measurements were carried out with a pH-meter model $\mathrm{pH}-150 \mathrm{M}$ equipped with a glass electrode ЭСК-10601/4 (Gomelsky Plant of Measuring Devices, Belarus). The $\mathrm{pH}$ value of each solution was established using diluted $\mathrm{HCl}$ and $\mathrm{NaOH}$ solutions.

\section{Results and discussion}

Our methods elaborated for osmium determination have been applied to the analyses of the ternary intermetallic systems $\quad \mathrm{Nd}_{20} \mathrm{Os}_{15} \mathrm{Si}_{65} \quad\left(\omega_{\mathrm{Os}}=37.7 \%\right.$ $(\mathrm{w} / \mathrm{w})), \mathrm{Nd}_{10} \mathrm{Os}_{30} \mathrm{Si}_{60}\left(\omega_{\mathrm{Os}}=64.6 \%(\mathrm{w} / \mathrm{w})\right)$.

\section{Dissolution of the intermetallide samples}

In spite of the chemical inertness of metallic osmium, osmium alloys can be dissolved in a mixture of concentrated $\mathrm{HCl}$ and $\mathrm{HNO}_{3}(10: 1)$ when heated. To obtain solutions of the analytes, 0.01-0.02 $\mathrm{g}$ of the intermetallic alloy were dissolved in $10-20 \mathrm{ml}$ of a mixture of the above-mentioned acids. The resulting mixture was boiled in a beaker in a sand bath for 1-2 hours. Under these conditions a residue of gray colour (metallic silicon) was observed at the bottom of the beaker. After quantitative transfer of the acidic solution into a $100.0 \mathrm{ml}$ volumetric flask the residue was dissolved in a small volume of $1 \mathrm{M}$ sodium hydroxide solution. The resulting alkaline solution was quantitatively transferred into the same volumetric flask and concentrated $\mathrm{HCl}$ was added to $\mathrm{pH} \leq 1$. Then distilled water was added to the volume of $100.0 \mathrm{ml}$.

\section{Determination of osmium(IV) in intermetallides}

For the analysis, aliquots of $0.5-2.0 \mathrm{ml}$ were taken. The osmium content was evaluated using the methods of single-point standardization, normal calibration curve, or standard additions, by means of the proper analytical procedure of determination (the conditions for the osmium determination are presented in Table 3).

The necessary quantities of appropriate sodium salt solutions (to maintain constant ionic strength), or buffer solutions, and the selected organic reagents were placed into a $25 \mathrm{ml}$ volumetric flask. Then the aliquots of Os(IV) solutions, containing $10^{-6}-10^{-5} \mathrm{~mol} \mathrm{l}^{-1}$ of osmium in the final volume, were added. A masking agent was added when it was necessary to eliminate the influence of neodymium(III). Distilled water was poured to a total volume of $\sim 15-20 \mathrm{ml}$. Then the proper $\mathrm{pH}$ value was established by means of diluted $\mathrm{NaOH}$ and $\mathrm{HCl}$ solutions. Distilled water was added to the mark and the solutions were heated in a boiling water bath $\left(\sim 95^{\circ} \mathrm{C}\right)$, if necessary. After cooling to room temperature $\left(\sim 20^{\circ} \mathrm{C}\right)$, absorbance measurements were 
Table 4 Results of the spectrophotometric determination of osmium(IV) in the alloy $\mathrm{Nd}_{20} \mathrm{Os}_{15} \mathrm{Si}_{65} \mathrm{n}=5$ (the number of independent measurements); $\mathrm{P}=0.95$ (the probability).

\begin{tabular}{|c|c|c|c|c|c|}
\hline Reagent & $\begin{array}{c}\omega_{\mathrm{Os}}{ }^{\text {calc }}, \% \\
(\mathrm{w} / \mathrm{w})\end{array}$ & $\begin{array}{l}C_{\mathrm{Os}}^{\text {calc }} \\
\mu \mathrm{g} \mathrm{ml}^{-1}\end{array}$ & $\begin{array}{l}C_{\mathrm{Os}} \text { pract. } \\
\mu \mathrm{g} \mathrm{ml} \mathrm{ml}^{-1}\end{array}$ & $\bar{\omega}_{o s}^{p r} \pm \frac{S \cdot t_{\alpha}}{\sqrt{n}}, \%(\mathrm{w} / \mathrm{w})$ & $\begin{array}{c}\text { Relative } \\
\text { standard } \\
\text { deviation, } \\
S_{r} \\
\end{array}$ \\
\hline Tropaeolin $\mathrm{O}$ & \multirow{6}{*}{37.7} & \multirow{6}{*}{86.8} & 87.9 & $38.2 \pm 0.5$ & 0.010 \\
\hline Tropaeolin OOO-I & & & 88.0 & $38.3 \pm 0.8$ & 0.014 \\
\hline Morin & & & 88.6 & $38.5 \pm 0.7$ & 0.015 \\
\hline Quercetin & & & 85.8 & $37.3 \pm 0.4$ & 0.010 \\
\hline Eriochrome Black T & & & 87.4 & $38.0 \pm 0.4$ & 0.010 \\
\hline Tiron & & & 85.61 & $37.2 \pm 1.1$ & 0.024 \\
\hline
\end{tabular}

Table 5 Results of the spectrophotometric determination of osmium(IV) in the alloy $\mathrm{Nd}_{10} \mathrm{Os}_{30} \mathrm{Si}_{60} ; \mathrm{n}=5$; $\mathrm{P}=0.95$ (the symbols are explained in Table 4).

\begin{tabular}{|c|c|c|c|c|c|}
\hline Reagent & $\begin{array}{c}\omega_{\mathrm{Os}}^{\text {calc }}, \% \\
(\mathrm{w} / \mathrm{w})\end{array}$ & $\begin{array}{l}C_{\mathrm{Os}}{ }^{\text {calc }} \\
\mu \mathrm{g} \mathrm{ml}^{-1}\end{array}$ & $\begin{array}{l}C_{\mathrm{Os}}^{\text {pract. }} \\
\mu \mathrm{g} \mathrm{ml}^{-1}\end{array}$ & $\bar{\omega}_{o s}^{p r} \pm \frac{S \cdot t_{\alpha}}{\sqrt{n}}, \%(\mathrm{w} / \mathrm{w})$ & $S_{r}$ \\
\hline Tropaeolin $\mathrm{O}$ & \multirow{6}{*}{64.6} & \multirow{6}{*}{319.3} & 324.0 & $65.6 \pm 0.8$ & 0.010 \\
\hline Tropaeolin OOO-I & & & 311.2 & $63.0 \pm 1.6$ & 0.021 \\
\hline Morin & & & 319.9 & $64.8 \pm 1.2$ & 0.015 \\
\hline Quercetin & & & 321.6 & $65.1 \pm 0.9$ & 0.012 \\
\hline Eriochrome Black T & & & 314.0 & $63.6 \pm 1.4$ & 0.017 \\
\hline Tiron & & & 310.6 & $62.9 \pm 1.3$ & 0.020 \\
\hline
\end{tabular}

carried out against a blank solution at the appropriate wavelength in $1-5 \mathrm{~cm}$ cuvettes. The results are presented in Tables 4 and 5.

It should be noted that the quantities of $\mathrm{SiO}_{3}{ }^{2-}$ ions present in the samples have not interfered the osmium determination for any of the analytical reagents used here.

It follows from Tables 4 and 5 that the results correlate well with the nominal osmium content in the alloys. The values of relative standard deviations $S_{r}$ do not exceed the typical values for $S_{r}$ in photometric analyses.

\section{Conclusions}

The possibilities of spectrophotometric determination of osmium(IV) in intermetallides has been shown. The methods do not demand any preliminary separation of osmium, nor the use of expensive or inaccessible reagents or apparatus. The results of the elaborated methods correlate well with each other and allow an accurate determination of the osmium content both in acidic and alkaline media. The average value of the osmium content determined in samples of different mass and using different reagents are similar. Concomitant ions in the solutions did not affect the carrying out of the analyses, or their influence was eliminated using EDTA as masking agent. The results are in agreement with the nominal osmium content in the alloys, taking into account the high osmium content in the samples. The duration of an analysis without preliminary sample preparation is approximately 1 hour.

\section{Acknowledgements}

The authors are grateful to Prof. R.E. Gladyshevskii for providing the samples used for our investigation.

\section{References}

[1] O.S. Bonishko, Spectrophotometry of Osmium(IV) Compounds with Triphenylmethane and Azo Dyes. Thesis, University of Kharkiv, 2008 (in Ukrainian).

[2] Yu.A. Zolotov, G.M. Varshal, V.M. Ivanov (Eds.), Analytical Chemistry of Platinum Group Metals, Collected Articles, Editorial URSS, Moscow, 2003, 592 p. (in Russian).

[3] R.L. Seth, A.K. Dey, J. Ind. Chem. Soc. 40(9) (1963) 794-796.

[4] C.S.P. Sastry, K.R. Rao, D.S. Prassad, Microchim. Acta 122(1-2) (1996) 53-60.

[5] I.V. Pyatnytskyi, L.L. Kolomiyets, N.D. Sulyma, Zh. Anal. Khim. 40(1) (1985) 115-119.

[6] M.I. Shtokalo, Ye.Ye. Kostenko, Zh. Anal. Khim. 45(2) (1990) 296-299.

[7] N.V. Arslanova, A.S. Myasoyedova, F.P. Sudakov, Zh. Anal. Khim. 26(5) (1971) 947-952. 
[8] K. Burger, Organic Reagents in Inorganic Analysis, Mir, Moscow, 1975, 262 p. (in Russian).

[9] N.L. Olenovich, L.I. Kovalchuk, Ye.P. Lozitskaya, Zh. Anal. Khim. 29(1) (1974) 47-51.

[10] A.T. Pilipenko, T.A. Vasilchuk, A.I. Volkova, Zh. Anal. Khim. 38(5) (1983) 855-861.

[11] A.B. Blank, L.E. Belenko, Zh. Anal. Khim. 33(1) (1978) 65-69.

[12] M. Balcerzak, E. Swiecicka, J. Anal. Chem. 61(2) (2006) 119-123.

[13] N.L. Olenovich, G.I. Savenko, Zh. Anal. Khim. 30(11) (1975) 2158-2162.

[14] A.P. Golovina, V.G. Tiptsova, Zh. Anal. Khim. 17(4) (1962) 524-525.

[15] O.S. Bonishko, M.V. Polko ${ }^{1}$, O.Ya. Korkuna, T.Ya. Vrublevska, Visn. Kharkiv Univ. Ser. Khim. 15 (38, 770) (2007) 70-75.

[16] M. Polko ${ }^{1}$, T. Vrublevska, O. Korkuna, M. Boyko, Visn. Lviv Univ. Ser. Khim. 49(1) (2008) 144-151.

[17] M.V. Polko ${ }^{1}$, O.P. Dobryanskaya, O.S. Bonishko, T.Ya. Vrublevskaya, $2^{\text {nd }}$ Int. Forum
"Analytics and Analysts", Voronezh, Russia, 2008, p. 647.

[18] G.M. Mykhalyna, T.Ya. Vrublevska, O.Ya. Korkuna, VIII Ukr. Conf. Anal. Chem., Odesa, Ukraine, 2008, p. 129 (in Ukrainian).

[19] T. Vrublevska, H. Mykhalyna, O. Korkuna, $19^{\text {th }}$ Int. Symp. Pharm. Biomed. Anal. PBA 2008, Gdańsk, Poland, 2008, p. 378.

[20] O.S. Bonishko, O.Y. Korkuna, T.Y. Vrublevska, $50^{\text {th }}$ Anniv. Pol. Chem. Soc. Pol. Assoc. Chem. Eng. Congr., $11^{\text {th }}$ EuCheMS-DCE Int. Conf. Chem. Environment, Toruń, Poland, 2007, p. 262.

[21] G. Turner, A.F. Clifford, C.N. Ramachandra Rao, Anal. Chem. 30(10) (1958) 1708-1709.

[22] R.R. Miano, C.S. Garner, Inorg. Chem. 4(3) (1965) 337-342.

[23] I.P. Alimarin, V.P. Khvostova, G.I. Kadyrova, Zh. Anal. Khim. 30(10) (1975) 2007-2018.

${ }^{1}$ Polko is the maiden name of M.V. Rydchuk 